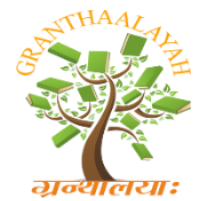

\author{
INTERNATIONAL JOURNAL OF RE
GRANTHAALAYAH \\ A knowledge Repository
}

Management

\title{
INFLUENCE OF WORK LIFE BALANCE ON PERFORMANCE OF EMPLOYEES IN JORDAN HOSPITALS
}

\author{
Mutaz Minwer Halal Al Harbi ${ }^{* 1}$ \\ ${ }^{* 1}$ Aligarh Muslim University, Aligarh, India
}

\begin{abstract}
This paper examines the impact of WLB on performance of employees in Jordan hospitals. This study is a quantitative research and made use primary data using a research questionnaire as instrument was administered to a total number of 500 respondents selected from four governments and four privates hospitals namely: Al-Bashir hospital (Government), Al Mafraq Government Hospital (Government), Ram Manohar Lohia Hospital (Government),Jawaharlal Nehru Medical College (Government),Philadelphia hospital (private), Haramain Hospital (Private), Jordan hospital (private) and Fortis Hospital (Private) from Jordan. The result of the study reveals that impact of WLB on performance of employees was significant and joint impact of WLB and motivation significantly influence performance of employees. In conclusion, motivation plays an important role in encouraging employees to perform; a well-motivated employee has a possibility of performing better than an employee that is not well motivated.
\end{abstract}

Keywords: Work Life Balance; Employee Performance; Motivation, Performance.

Cite This Article: Mutaz Minwer Halal Al Harbi. (2020). "INFLUENCE OF WORK LIFE BALANCE ON PERFORMANCE OF EMPLOYEES IN JORDAN HOSPITALS" International Journal of Research - Granthaalayah, 8(1), 53-58. 10.29121/granthaalayah.v8.i1.2020.247.

\section{Introduction}

The concept of Work life balance is a vital phenomenon and is of immense importance to different workers within public and private organizations. The phenomenon of Work Life Balance (WLB) is more than categorizing job functions and an individual's personal life. WLB equally determines the social, financial as well as psychological well-being of a person. These factors have been reflected in a worker's performance which influences the output of the individual at the place of work over a period of time. WLB has inference on workers' wellbeing, behavior and effectiveness of their companies Husain, U., \& Javed, S. (2019) and Eby et al (2005). The drawbacks of WLB could affect the employer and workers. As for the workers, the outcome could trigger an adverse effect on their job, psychological wellbeing, physical health as well as performance within their companies Javed, S. (2018, Guest, (2001). As for employers the outcome of ineffective WLB could lead to absenteeism, poor output, stress, sick leave as well as high level of turnover among the workers and increase in cost of training and recruitment. 
The concept of WLB is not just centered on childcare and families alone, neither is it on reduction in job functions. It is centered on working smart, being refreshed to contribute and give what is needed to work as well as home and not endangering any of the two. It is vital for all individuals; at any stage of life". (Khan, A. A., \& Javed, S. 2017 and Sarfaraz, J. 2017) Stress reduction as well as absenteeism via the flexibility of an employer should not just give rise to a satisfied as well as effective performance within work force; it must equally have a knock-on influence on enhanced recruitment facilities as well as retention". The accomplishment of an effective WLB can give rise to dividends for employers based on having an effective motivated, diligent, minimized stressed workforce, enhanced productivity, as well as low level of absenteeism.

The concept of performance can be seen as combining various variables, like capacity, motivation, condition of work as well as anticipation (Briscoe \& Schuler, 2004). According to Chandra \& Frank (2004) and Khan, A., \& Javed, S. (2016). performance evaluation systems are created to purposely assess the performance of employees as well as define steps needed to be taken in order to improve workforce, which is vital for the progress of an organization.

Another factor that affects the performance of employees is motivation. Ololube (2006) stated that motivations either intrinsic or extrinsic are vital to employees since they form the primary objective for working. Motivation connotes the complex forces and requirements that trigger the energy for a person to perform optimally (Shulze \& Steyn, 2003). Javed, S., Atallah Aldalaien, B., Husain, U., \& Shahfaraz Khan, M. (2019) and Azar \& Shafighi (2013) in their study noted that motivation will make workers of an organization to be more serious with their job and responsibilities. A good salary is an effective instrument that can play an important role in improving performance of employees and as well enhance an organization' level of productivity.

\section{Objectives of The Study}

The objectives of this study are as follows:

1) To determine the impact of WLB on performance of employees in Jordan hospitals.

2) To determine the impact of motivation and WLB on performance of employees in Jordan hospitals.

\section{Hypotheses}

The following hypotheses will be tested in this study:

Hypothesis One: $\mathrm{H}_{01}$ : There is a significant relationship between Work Life Balance and Employee Performance.

Hypothesis Two: $\mathrm{HO}_{2}$ : Motivation and work life balance have a significant effect employee performance in Jordanian hospitals.

\section{Literature Review}

In a comparative work of private and public hospitals at Chennai India carried out by Lakshmi et al (2012), the authors examined the Work Life Balance of female nurses. The findings showed that 53 percent of the nurses were battling to attain WLB. In their study, Khan, A., Baseer, S., \& Javed, 
S. (2017) and Akram \& Hassaan (2013) evaluated the influence of work-life conflict on job satisfaction among Pakistan doctors. Their result showed a significantly negative correlation between conflict (work-family intrusion as well as family-work intrusion) and satisfaction.

Ervin (2012) carried out a study on job satisfaction and WLB in Intercollegiate Athletic Graduate Supervisors and Assistants. The result showed that there was a significant difference within the groups.

\section{Methodology}

This study is a quantitative research and made use primary data using a research questionnaire as instrument was administered to a total number of 500 respondents selected from four governments and four privates hospitals namely: Al-bashir hospital (Government), Al Mafraq Government Hospital (Government), Ram Manohar Lohia Hospital (Government),Jawaharlal Nehru Medical College (Government),Philadelphia hospital (private), Haramain Hospital (Private), Jordan hospital (private) and Fortis Hospital (Private) from India and Jordan respectively. The data collated was analyzed using SPSS and the hypotheses were analyzed using Multiple Regression Analysis (Albashabsheh,et al . (2018).

Hypothesis One: There is a significant relationship between Work Life Balance and Employee Performance

Table 1: Multiple Regression of Work Life Balance and Employee Performance

\begin{tabular}{|l|l|c|c|c|c|c|}
\hline Model & & \multicolumn{2}{|c|}{$\begin{array}{c}\text { Unstandardized } \\
\text { Coefficients }\end{array}$} & $\begin{array}{c}\text { Standardized } \\
\text { Coefficients }\end{array}$ & t & Sig. \\
\cline { 3 - 7 } & & B & $\begin{array}{c}\text { Std. } \\
\text { Error }\end{array}$ & Beta & B & $\begin{array}{c}\text { Std. } \\
\text { Error }\end{array}$ \\
\hline \multirow{1}{*}{1} & (Constant) & -.378 & .198 & & -1.904 & .058 \\
\cline { 3 - 7 } & WorkFamilyCulture & .095 & .022 & .139 & 4.270 & .000 \\
\cline { 2 - 7 } & Autonomy & .550 & .054 & .396 & 10.213 & .000 \\
\cline { 2 - 7 } & FlexibleWorkArrangement & .681 & .033 & .675 & 20.680 & .000 \\
\cline { 2 - 7 } & WorkLifeConflictReduction & -.215 & .037 & -.216 & -5.846 & .000 \\
\cline { 2 - 7 } & WorkFamilyEnrichment & -.001 & .009 & -.002 & -.114 & .909 \\
\hline
\end{tabular}

a Dependent Variable: Employee Performance

Table 2: Model Summary

\begin{tabular}{|c|c|c|c|c|}
\hline Model & R & R Square & Adjusted R Square & Std. Error of the Estimate \\
\hline 1 & $.950(\mathrm{a})$ & .903 & .902 & .71003 \\
\hline
\end{tabular}

a Predictors: (Constant), Work Family Enrichment, Flexible Work Arrangement, Work Family Culture, Work Life Conflict Reduction, Autonomy

Table 3: ANOVA(b)

\begin{tabular}{|l|l|c|c|c|c|c|}
\hline Model & & Sum of Squares & df & Mean Square & F & Sig. \\
\hline \multirow{4}{*}{1} & Regression & 2306.513 & 5 & 461.303 & 915.028 & $.000(\mathrm{a})$ \\
\cline { 2 - 8 } & Residual & 249.045 & 494 & .504 & & \\
\cline { 2 - 8 } & Total & 2555.558 & 499 & & & \\
\hline
\end{tabular}

a Predictors: (Constant), Work Family Enrichment, Flexible Work Arrangement, Work Family Culture, Work Life Conflict Reduction, Autonomy b Dependent Variable: Employee Performance 
The multiple regression results analysis shows that Work Life Balance (Work Family Culture, Flexible Work Arrangement, Autonomy, Reducing Work Life Conflict Work Life Enrichment) significantly jointly influenced Employee Performance $\left[\left(\mathrm{R}^{2}=.903 ; \mathrm{F}(5,499)=915.028 ; \mathrm{p}<.05\right)\right]$. This infers that Work Life Balance (Work Family Culture, Flexible Work Arrangement, Autonomy, Reducing Work Life Conflict Work Life Enrichment) jointly accounted for about 90.3\% of the variance observable in employee performance. Furthermore, the independent contribution of Work Family Culture, Flexible Work Arrangement, Autonomy and Reducing Work Life Conflict were significant $(\beta=.095 ; \mathrm{t}=4.270 ; \mathrm{p}<.000),(\beta=.681 ; \mathrm{t}=.675 ; \mathrm{p}<.000)$, $(\beta=.550 ; \mathrm{t}=.396 ; \mathrm{p}<.000)$ and $(\beta=-.215 ; \mathrm{t}=-2.16 ; \mathrm{p}<.000)$ while Work family enrichment was not significant. In addition, Work Family culture, autonomy and flexible work arrangement were positively significant while Reducing Work Life Conflict was negatively significant. This shows that WLB significantly influence employee performance.

Hypothesis Two: Motivation and work life balance have a significant effect employee performance in Jordanian hospitals.

Table 4: Multiple Regression of Motivation and Work Life Balance on Employee Performance

\begin{tabular}{|l|c|c|c|c|c|}
\hline \multicolumn{6}{|c|}{ Table 4: Coefficients $^{\mathrm{a}}$} \\
\hline \multirow{2}{*}{ Model } & Unstandardized Coefficients Standardized Coefficients & \multirow{2}{*}{ Sig. } \\
\cline { 2 - 6 } & $\mathbf{B}$ & Std. Error & Beta & & \\
\hline 1 (Constant) & 4.413 & .544 & & 8.109 & .000 \\
\hline WLB & .107 & .017 & .297 & 6.142 & .000 \\
\hline Motivation & -.173 & .043 & -.195 & -4.027 & .000 \\
\hline
\end{tabular}

a. Dependent Variable: Employee Performance

Table 5: ANOVA $^{\mathrm{a}}$

\begin{tabular}{|l|l|c|c|c|c|c|}
\hline \multicolumn{2}{|l|}{ Model } & Sum of Squares & df & Mean Square & F & Sig. \\
\hline \multirow{4}{*}{1} & Regression & 128.136 & 2 & 64.068 & $19.861 .000^{\mathrm{b}}$ \\
\cline { 2 - 7 } & Residual & 1603.272 & 497 & 3.226 & & \\
\cline { 2 - 8 } & Total & 1731.408 & 499 & & & \\
\hline
\end{tabular}

a. Dependent Variable: Employee Performance

b. Predictors: (Constant), Motivation, WLB

Table 6: Model Summary

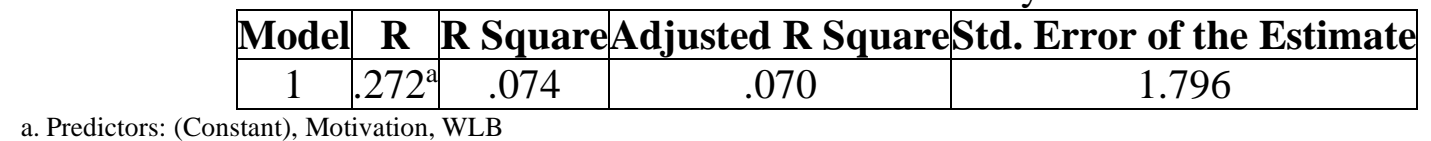

The multiple regression results analysis shows that Work Life Balance and motivation jointly significantly jointly influenced Employee Performance $\left[\left(\mathrm{R}^{2}=.074 ; \mathrm{F}(2,499)=19.861 ; \mathrm{p}<.05\right)\right]$. This infers that Work Life Balance and motivation jointly accounted for about $7.4 \%$ of the variance observable in employee performance. Furthermore, the independent contribution of Work Life Balance and Motivation were significant $(\beta=.297 ; \mathrm{t}=6.142 ; \mathrm{p}<.000)$ and $(\beta=-.195 ; \mathrm{t}=-4.027$; $\mathrm{p}<.000)$. In addition, work life balance was positively significant while motivation was negatively significant. This shows that both Work Life Balance and Motivation significantly influence employee performance. 


\section{Conclusion}

The result of the first hypothesis shows a significant relationship between WLB and employee performance while the result of the second hypothesis showed that the joint effect of motivation and WLB on performance of employees was significant. This finding agrees with Kamau et al (2013) who examined WLB on Performance of employees in Eco bank, located at Kenya. The result of the study shows a correlation within performance of employees and WLB. Also, Dissanayaka et al (2013) who investigated the influence of WLB on performance of employee showed a positively significant correlation between WLB and employee performance. In conclusion, motivation plays an important role in encouraging employees to perform; a wellmotivated employee has a possibility of performing better than an employee that is not well motivated.

\section{References}

[1] Akram, A. \& Hassan, M. (2013). Impact of Work Life Conflict on Job Satisfaction, Interdisciplinary Journal of Contemporary Research in Business, 5 (8), pp. 437-448.

[2] Azar, M \& Shafighi, A. (2013). The Effect of Work Motivation on Employees' Job Performance: International Journal of Academic Research in Business and Social Sciences, Vol. 3, No. 9 ISSN: 2222-6990.

[3] Briscoe, D. \& Schuler, R. (2004), "International Human Resource Management" 2nd Ed., Routledge.

[4] Chandra, A. \& Frank, ZD (2004), "Utilization of performance appraisal systems in health care organizations and improvement strategies for supervisors", Health Care Manag (Fredrick), Jan Mar 23(1):25-30.

[5] Dissanaya. M \& Hussain, A. (2013) Impact of work life balance on employees performance an empirical study on seven apparel organization in Sri Lanka. Proceedings of the third International Symposium

[6] Dr. Aisar Ayed Nahar Albashabsheh, Dr. Modafar Nayel Alhroob, Dr. Belal Eid Irbihat, and Dr. Sarfaraz Javed. (2018). "Impact Of Accounting Information System In Reducing Costs In Jordanian Banks." International Journal of Research - Granthaalayah, 6(7), 210-215. https://doi.org/10.5281/zenodo.1336672.

[7] Eby, L.T., Casper, W.J., Lockwood, A., Bordeaux, C., \& Brindley, A. (2005). Work and family research in IO/OB: Content analysis and review of the literature (1980-2002). Journal of Vocational Behaviour, 66, 124-97.

[8] Ervin, M.S. (2012). A Comparative Analysis of Work-Life Balance in Intercollegiate Athletic Graduate Assistants and Supervisors. Doctoral dissertation, Georgia State University. Available at: http://scholarworks.gsu.edu/cgi/viewcontent.cgi article=1003\&context=kin_health_thesis.

[9] Guest, D. (2001), 'Perspectives on the study of work-life balance', Discussion paper prepared for the 2001 ENOP Symposium, Paris, 29-31 March, http://www.ucm.es/info/Psyap/enop/guest.htm

[10] Husain, U., \& Javed, S. (2019). Stock Price Movement and Volatility in Muscat Security Market (Msm). International Journal of Research-Granthaalayah, 7(2), 68-84.

[11] Javed, S. (2018). Does Organisation Behaviour Affect Performance Of Auditing Firms? https://doi.org/10.5281/zenodo.1171842

[12] Javed, S., Atallah Aldalaien, B., Husain, U., \& Shahfaraz Khan, M. (2019). Impact of Federal Funds Rate on Monthly Stocks Return of United States of America. International Journal of Business and Management, 14(9), 105. doi:10.5539/ijbm.v14n9p105 
[13] Khan, A. A., \& Javed, S. (2017). A study of volatility behaviour of S\&P BSE BANKEX return in India: A pragmatic approach using GARCH model. International Journal of ADVANCED AND APPLIED SCIENCES, 4(4), 127-132. doi:10.21833/ijaas.2017.04.018

[14] Khan, A., \& Javed, S. (2016). Determining Factors Responsible in Shifting Consumption of Mobile Data (2G to 3G). International Journal of Computer Applications, 155(14), 30-33. doi:10.5120/ijca2016912452

[15] Khan, A., Baseer, S., \& Javed, S. (2017). Perception of students on usage of mobile data by Kmean clustering algorithm. International Journal of advanced and applied sciences, 4(2), 17-21. doi:10.21833/ijaas.2017.02.003

[16] Kamau, J. M, Muleke V, Makaya S. O, \& Wagoki, J. (2013) Work life balance practices on employee performance of Ecobank Kenya. European journal business and management, 5(25), 179-185.

[17] Lakshmi, K.S., Ramachandran, T. \& Boohene, D. (2012), "Analysis of Work Life Balance of Female Nurses in Hospitals - Comparative Study between Government and Private Hospital in Chennai, TN., India" - International Journal of Trade, Economics and Finance, Vol. 3, No. 3, June 2012

[18] Ololube, P.N. (2006). Teachers Job Satisfaction and Motivation for School Effectiveness: An Assessment. Article in Essays in Education .

[19] Sarfaraz, J. (2017). Unified Theory of Acceptance and Use of Technology (UTAUT) ModelMobile Banking. Journal of Internet Banking and Commerce, 22(3), 1-20.

[20] Schulze, S., \& Steyn, T., (2003). Educator's motivation: differences related to gender, age and experience. Acta Academia, 35(3), 138-160.

\footnotetext{
*Corresponding author.

E-mail address: Mutaz1910@ gmail.com
} 